DOI https://doi.org/10.30525/978-9934-26-004-9-11

\title{
ЛИТІ МЕТАЛЕВІ ДВЕРІ ЄВРОПЕЙСЬКИХ КУЛЬТОВИХ СПОРУД
}

\author{
Михайлова Р. Д. \\ доктор мистеитвознавства, \\ професор кафедри дизайну інтер 'єру і меблів \\ Чверкалюк К. О. \\ студентка IV курсу кафедри інтер' 'ру і меблів \\ Київського наиіонального університету технологій та дизайну \\ м. Київ, Україна
}

Литі металеві двері європейських культових споруд несуть у собі історичне, художнє, естетичне, композиційне, змістовне значення [1;2]. Поєднуючи утилітарно-побутову функцію та сакральний зміст, двері храму, за словами Євангелія від Іоана, прямо відображають тему Христа : «Я єсмь двері: хто увійде Мною, той спасеться» (Ин.10:9). Двері храмів також представляють собою мистецькі твори, дослідженню яких як окремій проблематиці приділялося недостатньо [3].

Попри окремі згадки стародавнього часу, як, наприклад, металеві двері храмів у Священному писанні, історичні зразки литих дверей демонструють європейські культові споруди, що належать добі середньовіччя. Найдавніші з них, які датують XI-XII ст. спочатку були поширені у Візантії, де працювали майстри, продовжувачі традицій ранніх цивілізацій Сходу. У Візантії металеві двері замовляли для європейських храмів. Двері із Константинополя мали свідчити про близькість храмової споруди в Свропі до Візантії та ії церкви.

Замовниками візантійських металевих дверей ставали знані патриції, богаті аристократи, церковні діячі. За міськими документами відомо, у 60-90ті pp. XI ст. в Константинополі литі бронзові двері замовляли іпат Панталеоне для храмів міст Амальфі, Монте Гаргано, Атрані, ломбарцієць Ландольфо Брутомило для храму в Салерно, абат Дезидері для Монтекасіно. Відомий європейський церковний діяч доби середньовіччя Гільдебрандт, в майбутньому папа Григорій VII, був замовником дверей для церкви Сан Паоло у Римі, а єпископ Бернвард бронзових дверей для собору Св. Михаїла у Гільдесгеймі в Німеччині, які були створені між 1008 та 1015 рр. У ХІІ ст. в Константинополі були 
вилиті двері, які прикрасили вхід собору Сан Марко у Венеції. Подібні двері вели із атріуму до каплиці Дзен.

У XIV ст. двері стали виливати в самій Італії: другі зліва двері фасаду Сан Марко - робота венеційського майстра Бертолуччі, який залишив свій підпис та дату - 1300 рік. Вони органічно поєдналися із декором порталів церкви, перетвореної у XII-XIV ст. на собор. Головна культова будівля Венеціанської республіки отримала п’ять порталів із п'ятьма входами, прикрашеними двома ярусами колон, арками зі скульптурним орнаментом, мозаїками та мармуровим декором у напівкруглих тимпанах над входами, що гармонійно узгоджувалися з орнаментами і мозаїками другого ярусу. На центральному порталі горельєфи зображували сцени мисливства та риболовлі - важливих для Венеційської республіки промислів. Композиція головного порталу відтворювала сцену «Страшного суду», а чотири інші - історію вивезення з Єгипту тіла Св.Марка та його прибуття до Венеції. Мозаїки над іншими входами «Викрадення тіла Св. Марка з Олександрії», «Прибуття тіла Св. Марка у Венецію», створені за малюнками відомих художників-монументалістів П’єтро делла Веккія та Себастіано Річчі [4]

Суцільнометалеві двері, які створювали у Європі, виливали за модулем, винайденим, імовірно, німецькими майстрами. Їх технічноінженерний досвід грунтувався на знаннях, накопичених ремісникамиливарниками, які спеціалізувалися на виготовленні монументальних металевих творів, зокрема надгробків та дзвонів. Найбільш знамениті суцільнометалеві двері прикрашали собори у Гільдесгеймі та в Аугсбурзі (XI ст.) у Німеччині, кафедральний собор Успіння Діви Марії в Гнєзно (XI ст.) у Польщі, собор Беневенте у Вероні (XII ст.) в Італії.

Так, з майстрами із Магдебурга пов'язують литі бронзові двері XI ст. церкви Сан Дзено у Вероні. У XII ст. вони були оновлені: на правій стулці з'явилися сцени із Нового та Старого заповіту у романській стилістиці, а ліва, більш рання, залишилася за стилем наївнореалістичною.

Двері собору Гільдесгейма прикрашали шістнадцять рельєфів на сюжети Біблії та Євангелія. Попри певну наївність художньої мови, багатофігурні рельєфи відрізняла емоційна живість та природність. У сцені, де розгніваний Бог постає перед порушниками його заборон Адамом та Євою, Адам виправдовується, вказуючи на винуватицю Єву та спокусителя-змія.

Двусдвустульчасті бронзові двері кафедрального собору у Гнєзно прикрашали рельєфи зі сценами із життя Войцеха-Адальберта (Adalbertus Pragensis, польськ.Wojciech) - святого патрона католицької 
церкви, який у 80-х - на початку 90-х рp. Х ст. перебував 3 християнською місією у Гданьську і на шляху до Прусії загинув від рук язичників. Войцех-Адальберт $є$ святим патроном Польщі, Чехії, Угорщині та Прусії.

3 XII ст. між німецькими та італійськими майстрами почалися змагання: італійці прагнули перевершити німецьких у художній майстерності. Проте справжніх висот вони досягли у добу Відродження, коли до створення церковних дверей долучилися видатні скульпторибронзоливарники. Особливої слави зазнали двері Флорентійського баптистерію, збудованого 1059 р. У період між XIV та XVI ст. його прикрасили трьома бронзовими дверями. Замовниками північних та східних дверей у 1401 р. стали багаті флорентійські цеховики. У конкурсі зі створення композиції на тему «Жертавоприношення Авраама» із семи представлених робіт перемогли два видатні скульптори раннього Відродження - Лоренцо Гіберті (бл.1378-1455) та Філіппо Брунеллескі (1377-1446). Однак відзначений новизною та сміливістю рішень проект Брунеллескі надалі було відхилено на користь більш традиційного, який запропонував 23-річний скульптор Гіберті.

Північний вхід він оформив за взірцями, створеними у 1330-1336 pp. готичним скульптором Андреа Пізано, підкресливши зв'язок минулого та сучасного. Л.Гіберті створив 28 невеликих рельєфів у готичному обрамленні. Двадцять 3 них присвячені євангельській історії, решта образам євангелістів та батьків церкви. Події євангельської легенди автор відтворив з високою долею поетичності, так, що живе почуття схвильованості передавалося глядачам. Свої композиції він збагатив численними реалістичними деталями. Події розгорталися на тлі міської архітектури та природного італійського ландшафту - скель, каменів, моря. Між полями рельєфів Л.Гіберті розмістив декоративні гірлянди 3 пагонів виноградної лози, а на перетині гірлянд у високому рельєфі зобразив портрети сучасників - скульпторів та каменотесів, які допомагали йому у роботі. Серед інших Лоренцо Гіберті залишив нащадкам і власний автопортрет.

Робота, яка захопила Гіберті, стала справою його життя. Впродовж 1402 - 1424 рр. він працював над створенням північних дверей, а у 1425-1452 pp. - східних. Одному лише декору він віддав дванадцять років праці, яку завершив навесні $1452 \mathrm{p}$.

Досягненням скульптора стали східні двері, які, за свідченням першого європейського історика мистецтва Джоржо Вазарі, викликали загальне здивування виразністю пластики. У десяти рельєфах, що розкривали ключові сюжети Старого заповіту, Гіберті досягнув 
небаченої до того образно-змістовної глибини. Робота Л.Гіберті над дверима вражала новизною й новаторством: вона поєднала композиційні форми, вироблені попередниками та нову філософію художнього твору. Двері Гіберті стали взірцем для скульпторів-початківців, що опановували мистецькою школою, та, водночас, зрілих мистців, які оцінити новаторство праці. Ідеї Гіберті підхопили та розвинули живописець Паоло Учелло, скульптор Донателло, архітектор Б. ді Микелоццо. Подив сучасників викликав також незвичний архітектурний пейзаж, який відтворював образ рідного міста. Вони оцінили також технічні новації, зокрема світлотіньові ефекти, що наближали рельєфи Гіберті до живописного твору. Геніальний скульптор Мікельанджело Буонарроті назвав роботу Гіберті «дверями раю».

Грандіозний задум Лоренцо Гіберті та його здійснення знайшли подальший розвиток у світовій художній культурі. Копії рельєфів Гіберті прикрашають північні ворота Казанського собору у Санкт-Петербурзі, зведеного за проектом А.І.Вороніхіна у 1801-1811 pp. Наприкінці XIX ст. двері Гіберті надихнули французького скульптора-імпресіоніста Огюста Родена на створення «Воріт пекла» музею Д’Орсе у Парижі, образ яких - «Мислитель» - став найславетнішим зразком новітньої скульптури. У XX ст. двері Гіберті стали прикладом для італійського скульптора Джакомо Манцу, якому належить композиція гігантських семиметрових дверей собору Святого Петра у Римі.

Традиції виготовлення та декорування литих металевих дверей європейських культових споруд суттєво доповнює історію культури та мистецтва, надаючи ій історичної конкретності та образно-естетичної глибини. Їх дослідження може бути застосовано в сучасних мистецьких, архітектурних та дизайнерських проектах. .

\section{Література:}

1. Михайлова Р. Д. Брама у просторі і часі. К.: КНУТД, 2020.188 с.

2. Михайлова Р.Д., Ковальчук В. «Райські двері» Лоренцо Гіберті // Наукові розробки молоді на сучасному етапі: тези доповідей XVIII Всеукраїнської конференції молодих учених та студентів (17-18 квітня 2019 р.). К.: КНУТД, 2019. Т. 1. С. 466-467. http://biblio.knutd.edu.ua/conference/2019/NRMSE2019_V1.pdf

3. Тимофієнко В. І. Брами, огорожі й ворота у забудові південних міст. - К.: НДІТІАМ; ІМФЕ, 1994. 67 с.

4. Madden Thomas. Venice: A New History. New York: Viking, 2012. $465 \mathrm{~s}$. 